\title{
Some Notes on Historical, Theoretical, and Empirical Background of DSGE Models ${ }^{1}$
}

\author{
Martin Slanicay ${ }^{2}$
}

\begin{abstract}
In this paper I present the historical, theoretical and empirical background of DSGE models. I show that the fundament of these models lies in optimizing agents framework and argue which impulses fueled the development of DSGE models. I demonstrate the evolution of DSGE models with an accent on the role and effects of the monetary policy, using distinction between RBC models and New Keynesian models. I explain the paradigm shift from the RBC models to the New Keynesian models by pointing out the main pitfalls of the RBC models and showing how adding nominal rigidities to the otherwise standard RBC models enhances empirical properties of these models. I also discuss how nominal rigidities are modeled in New Keynesian DSGE models and what the pros and cons of different approaches are. Finally, I review the most important New Keynesian theories of nominal rigidities and some of the empirical evidence on price and wage rigidities.
\end{abstract}

Key words: DSGE model, RBC, New Keynesian, monetary policy, business cycle, price rigidity, wage rigidity

JEL Classification: B22, E32

\section{Motivation}

DSGE models represent the core of contemporary macroeconomics focusing on monetary policy and business cycle. In a practical way, they are widely used by central banks for monetary policy analyses and forecasting. Therefore, it is important to know why these models emerged and how they have evolved. Knowing about motivation which formed the basis of their development helps us understand the abilities and limits of these models.

In this paper I therefore present the historical, theoretical, and empirical background of DSGE models. At first I show that the fundament of these models lies in optimizing agents framework. Subsequently, I argue which impulses fueled the development of DSGE models, and that all of them were related to the widened dissatisfaction of economists with large scale neo-Keynesian macroeconometric models, on both theoretical and practical levels. The evolution of DSGE model is demonstrated with an accent on

\footnotetext{
${ }^{1}$ This work was supported by funding of specific research at ESF MU, project MUNI/A/0775/2013. I also thank Jan Čapek, Mirek Hloušek, and two anonymous referees for their helpful comments and suggestions.

${ }^{2}$ Masaryk University, Faculty of Economics and Administration, Department of Economics, Lipová 41a, Brno 602 00, slanicay@mail.muni.cz
} 
the role and effects of the monetary policy, and a distinction between RBC models and New Keynesian models is used. ${ }^{3}$ I discuss the main features of both RBC and New Keynesian models and explain the paradigm shift from the RBC models to the New Keynesian models by pointing on the main pitfalls of the RBC models and showing how adding some "Keynesian" assumptions, namely nominal rigidities, to the otherwise standard RBC models enhances empirical properties of these models. I also discuss how these assumptions are modeled in New Keynesian DSGE models and what the pros and cons of different approaches are. Consequently, I review the most important New Keynesian theories of nominal rigidities and some of the empirical evidence on price and wage rigidities.

The rest of this paper proceeds as follows. The next section presents the nature of DSGE models, explain what the impulses for creation of such models were, and show how these models evolved over time, and why. Section 3 discusses the most important New Keynesian theories of price and wage rigidities. Section 4 reviews some of the empirical evidence on price and wage rigidities. The last section concludes.

\section{History}

Nature of DSGE Models

DSGE is an acronym for Dynamic Stochastic General Equilibrium. DSGE models are dynamic macroeconomic models of business cycle behavior of an economy. Their distinctive feature is that they are derived from the microeconomic foundations. These models usually assume optimizing agents ${ }^{4}$ which usually form rational expectations ${ }^{5}$ and maximize their objective functions subject to their respective constraints.

\footnotetext{
${ }^{3}$ There is a lot of different specifications of these models, with different assumptions which reflect the purpose for which these models were developed. Certainly, there is a difference between the "policy" models used by central banks for monetary policy analysis, and the "academic" models. The former contains all the bells and whistles in order to fit the macroeconomic data and provide reliable predictions, while the latter are highly stylized. Nevertheless, "policy" models are build on the grounds of "academic" models and the key features of "academic" and "policy" models, such as intertemporal optimization or Phillips curves, are very similar. Therefore, it seems correct to demonstrate the evolution of DSGE models using references to "academic" models, although "policy" models used by central banks are slightly more sophisticated.

${ }^{4}$ Certain DSGE models assume non-optimizing agents which follow some kind of rule-of-thumb. As an example, we could mention the concept of non-ricardian households, proposed by Mankiw (2000), which is often used in DSGE models with government sector, for example see Coenen and Straub (2005). In order to get plausible impulse-responses of consumption to fiscal shocks, it seems that the model must contain some portion of non-optimizing households which deplete all their earnings in each period. This type of households is often labeled also as hand-to-mouth households.

${ }^{5}$ One of the trends in the recent development of DSGE models is to relax the assumption of rational expectations. Researchers try to develop and improve models with bounded rationality, such as models with some learning mechanism of forming expectations, for example see Slobodyan and Wouters (2012).
} 
Let us take an example. ${ }^{6}$ All these models usually assume representative households and firms. Households consume goods, supply labor, trade bonds or accumulate capital in order to maximize their utility function subject to numerous constraints (e.g. the budget constraint, labor demand constraint, Calvo constraint on the frequency of wage adjustment, law of motion for the capital, etc). Firms, on the other hand, produce goods and hire labor, trying to maximize their stream of profits subject to their respective constraints (e.g. the demand constraint and the Calvo constraint on the frequency of price adjustment). DSGE models are usually complemented by a reaction function of a central bank which takes the form of a variant of Taylor rule.

\section{Shortcomings of Neo-Keynesian Models}

The development of DSGE models, which began in the 1980s, was fueled by several impulses originated in the 1970s. These impulses were mainly connected with the practical failure of large-scale neo-Keynesian macroeconometric models as forecasting tools, and with widened dissatisfaction of economists with theoretical underpinning of these models.

When Keynes published his General Theory in 1936, see Keynes (1936), it became an impulse for construction of large-scale macroeconometric models in a Keynesian style. These models took the form of a system of equations with ad-hoc postulated decision rules for the development of modeled variables inspired by the Keynesian macroeconomic theory. The beginning of these models can be dated to the late 1940s and they were most successful in the 1950s and 1960s; for example of these models see Klein and Goldberger (1955). The 1970s, however, witnessed the beginning of decline of these neo-Keynesian models and their ad-hoc modeling approach. There were several reasons for that.

From the practical point of view, these neo-Keynesian models began to fail in their function of forecasting tools. The reason was obvious. The dynamics of these models depended heavily on the alleged trade-off between inflation and unemployment, expressed by the Phillips curve. Therefore, it was difficult for these models to explain the simultaneous increase of inflation and unemployment which occurred in the course of the 1970s. A number of empirical studies pointed out the weak forecasting performance of such models, often suggesting that simple statistical extrapolation of time series, with no connection to the economic theory, provides better forecasting performance than these structural neo-Keynesian models. For example of this literature see Nelson (1972).

From the theoretical point of view, economists became dissatisfied with the theoretical underpinning of these neo-Keynesian models. They criticized the disequilibrium nature of these models and the lack of microfoundations for their main assumptions of price and wage rigidities. This wave of criticism inspired the research program of New Keynesian economics whose proponents sought for microfoundations of price and wage

${ }^{6}$ This paragraph is intended to serve as a non-technical example of the usual structure of DSGE models for those readers who are not familiar with these models. Thus, the description of the model structure is inevitably arbitery, and it is possible to rewrite each sentence of this paragraph and still assume we are talking about DSGE models. Therefore, this paragraph does not have any ambitions to describe all different sorts and branches of DSGE models. 
rigidities. ${ }^{7}$ Also, after the seminal paper of Muth (1961), who introduced the concept of rational expectations, economists became widely dissatisfied with the ad-hoc treatment of expectations in the form of adaptive expectations in these models. However, the most fundamental criticism of these neo-Keynesian models, known as the Lucas critique, can be found in Lucas (1976). Lucas criticized usefulness of ad-hoc constructed large-scale macroeconometric models for predictions of effects of changes in economic policy, arguing that predictions of such effects, based entirely on the relationships observed in the historical data, are useless. He claimed that because the parameters of those models are not structural, i.e. not policy-invariant, they will necessarily change whenever an economic policy is changed. Therefore, policy conclusions based on these models would be potentially misleading.

\section{Evolution of RBC Models}

The development of DSGE models is connected to an effort to derive a model which would be more immune to the Lucas critique, i.e. a model containing parameters which could be considered independent of the economic (monetary) policy. That is why DSGE models came into existence. These models are derived from microeconomic foundations and their parameters are functions of some "deep parameters", such as discount factor, elasticity of substitution among goods, elasticity of intertemporal substitution, elasticity of labor supply, etc. These "deep parameters" (related to preferences, technology and resource constraints) can be regarded as independent of the monetary policy.

Seminal papers by Lucas and Prescott (1971) and Lucas (1972) can be considered as the predecessors of DSGE models. Some authors, e.g. Diebold (1998) or Woodford (2003), label these models as New-Classical models and consider them to be the first generation of DSGE models. From the historical perspective, these authors divide DSGE models into three groups: (i) New-Classical models, (ii) Real Business Cycle models, and (iii) New Keynesian models. By contrast to them, Galí (2008) considers only the latter two groups of models as DSGE models. I prefer Galís sorting for the following reason. Although the New-Classical models, represented by Lucas and Prescott (1971) or Lucas (1972), employ optimizing agents framework, their analysis is only partial in the sense that each paper focuses on a part of an economy only. For example, Lucas and Prescott (1971) examine the investment behavior of a firm which faces stochastic demand, however, the demand is postulated ad-hoc, and thus does not result from optimizing behavior of households. Similarly, Lucas (1972) examines optimizing behavior of households, however, the supply side of the economy is not explicitly modeled there.

In my view, the first DSGE model was formed by Finn E. Kydland and Edward C. Prescott, see Kydland and Prescott (1982). Their concepts became the core of the real business cycle (RBC) theories. After their seminal paper had been published, many other RBC models appeared, for example see Prescott (1986) or Long and Plosser (1983), each of them with different assumptions and purposes. All of them had several common features, though. RBC models in general assume perfect competition on the goods and labor markets and flexible prices and wages. The concept of RBC models

\footnotetext{
${ }^{7}$ A representative collection of the most influential papers can be found in Mankiw and Romer (1991a) and Mankiw and Romer (1991b).
} 
caused extensive reactions. There were three reasons for that: (i) the methodological approach described above; (ii) success in matching some business cycles patterns; and (iii) policy implications of these models.

The calibrated RBC models were successful in matching some patterns of unconditional second moments of a number of macroeconomic time series, including their relative standard deviations and correlations, see Long and Plosser (1983) or Prescott (1986). King and Rebelo (1999) also show that after plugging the actual sequence of technology shocks (proxied by the estimated innovations in an AR process for the Solow residual) as an input in the RBC model, the resulting equilibrium paths of output and labor input match the observed historical patterns of those variables surprisingly well. A nice survey of the contributions of RBC models to our understanding of business cycle fluctuations, as well as a discussion of some open issues and recent trends in DSGE modeling can be found in Rebelo (2005).

When it comes to the policy implications, RBC models imply that the business cycle is primary caused by real forces, especially by productivity shocks. Given the main assumption of these models that individuals and firms respond optimally to these shocks and that there are no frictions (nominal or real), recession is a result of optimal decisions of individuals in the economy and does not, therefore, represent a period with an inefficient allocation of resources. Moreover, economic policy focusing on eliminating such deviations is not desirable because these business cycle fluctuations are, through the lens of RBC models, optimal. Technological progress was given a new interpretation. Traditionally, economists had viewed technological progress as a source of long-term growth unrelated to business cycles. In RBC models, nonetheless, technological progress became the main source of economic fluctuations.

\section{Shortcomings of RBC Models}

The controversial policy implications of RBC models made many researchers empirically evaluate the impact of technology shocks. ${ }^{8}$ They employed distinct methodology, empirical strategy and used various data, however, they all brought similar results. They provided unambiguous evidence that (i) positive technology shocks generate a negative short-run comovement of output and labor input, thus causing unemployment rate to rise in the short run; and (ii) the contribution of technology shocks to the business cycle fluctuations is quantitatively small. These findings reject the key predictions of the RBC models, namely (i) positive comovement of output, labor input, and productivity in response to technology shocks; and (ii) technology shocks as the dominant source of business cycle fluctuations.

Neutrality of the monetary policy is another controversial implication of RBC models. According to majority of RBC models, monetary policy has no effects on real variables even in the short run. ${ }^{9}$ Neutrality of monetary policy is strongly at odds with the long and widely held belief of economists that monetary policy has the power to influence

\footnotetext{
${ }^{8}$ A nice survey of this literature can be found in Galí and Rabanal (2005).

${ }^{9}$ The monetary policy is slightly non-neutral in a few RBC models but its effects on real variables is very limited and almost negligible. These models assume either the utility function of households, which is non-separable in real money balances, or "cash in advance" constraint.
} 
output and unemployment, at least in the short run, see the narrative evidence of Friedman and Schwartz (1963), or a more recent paper by Christiano, Eichenbaum and Evans (1998).

A tough criticism of RBC models, namely the model assumptions and implications of Prescott (1986), can be found in Summers (1986), who criticizes the approach towards parameterization of the model, arguing that the model parameters, namely (i) the share of household time devoted to market activities, (ii) average real interest rate, and (iii) elasticity of labor supply, are calibrated to extremely unrealistic values. He also calls into questions the interpretation of movements in TFP as technological shocks, arguing that real sources of technological regress are hard to find and that movements in TFP can actually be the result of labor hoarding. However, the main objection to Prescott's analysis is that it neglects the nominal variables, namely price level and inflation. The model also does not offer any explanation for exchange failures observed during economic downturns.

\section{Evolution of New Keynesian Models}

All shortcomings of RBC models mentioned above led to evolution of the so-called New Keynesian models (henceforth NK models). New Keynesian models adopted the methodology and the underlying structure of RBC models, i. e. principles of optimizing agents. However, unlike RBC models, NK models were enhanced with some "Keynesian" assumptions, namely monopolistic competition on the goods and/or labor markets, price and wage rigidities, etc. ${ }^{10}$ It can be argued that labeling these models as "Keynesian" can be slightly misleading. There are no traditional Keynesian concepts of effective aggregate demand, spending and investment multipliers, investment accelerator or liquidity trap. Several authors, see Goodfriend and King (1997), call this new paradigm the "new neoclassical synthesis". This name originates from the fact that the models have "classical" spirit of clearing markets, and economies are supposed to have certain self-regulating power. In the case of an unanticipated shock, the economy deviates from its equilibrium, however, after a certain amount of time it reverts back to the equilibrium. The length of the adjustment process is influenced by the degree of nominal and real rigidities. Graduality of the adjustment process makes room for potential welfare enhancing economic (monetary) policy which can minimize the distortions, and thus stabilize the economy around its equilibrium. From my point of view, it is rather neoclassical macroeconomics enhanced by some "Keynesian" assumptions which make these models more realistic.

The distinction between New Keynesian models and RBC models is primarily based on assumptions of price and wage rigidities. Inclusion of price and wage rigidities into the model leads to different implications of the model. Monetary policy is no longer neutral

\footnotetext{
${ }^{10}$ The relation between RBC models and NK models can be best explained by the fact that NK models often use RBC model equilibrium as a benchmark for measuring ineffectiveness arising from nominal rigidities and monopolistic competition. In fact, some NK DSGE models define output gap as a difference between the actual level of output and the natural level of output, where the latter is defined as an equilibrium of corresponding RBC model. Therefore, RBC models should be viewed as a point of departure for NK models.
} 
in the short run. As a consequence of the presence of nominal rigidities, changes in the short-term nominal interest rate are not offset by identical changes in the expected inflation, thus causing real interest rate to vary over time. Shifts in real interest rate cause changes in consumption and investment, which in turn bring changes in output and employment, the reason for that being that firms find it optimal to adjust their production to the new level of aggregate demand. In the long run, however, all prices and wages adjust, and the economy returns to its natural equilibrium.

\section{Modeling of Nominal Rigidities in New Keynesian Models}

Much empirical evidence proves that prices and wages do not change frequently, see survey in the last section. Also, extensive literature of New Keynesian economics provides theoretical justification for the assumption of price and wage stickiness, see discussion in the next section. Although all of the discussed theories can be seen as valid, it seems impossible to model them jointly in one model.

There are two main approaches towards modeling of nominal rigidities in New Keynesian DSGE models: Calvo (1983) and Rotemberg (1982). Both approaches lead to FOC equation which can be transformed (under some conditions) into the Phillips curve equation which links current and expected inflation with marginal costs. The resulting equations are very similar and also imply similar inflation dynamics.

Calvo (1983) develops a model in continuous time in which each firm is allowed to change its price only when it receives a random signal. Firms follow a perfect-foresight equation for the price-setting. In the Yun (1996) extension, firms are maximizing present value of real profits when they set prices. According to the Calvo-Yun setup, only 1- $\theta$ portion of firms (randomly chosen) can set their prices optimally in each period, while $\theta$ portion of firms leave their prices unchanged. Under such assumption, when firm is allowed to reset its price optimally, it takes into account the fact that it shall not be able to do it again for a certain amount of time. Therefore, firms choose their prices in order to maximize the discounted sum of their current and future profits, given the probability that their prices remain effective in the subsequent periods. The optimization problems of firms lead, after some mathematical manipulation, to the derivation of key equations in New Keynesian DSGE models: New Keynesian Phillips curve.

Erceg, Henderson and Levin (2000) propose an application of Calvo mechanism for wage dynamics. In their setup, households choose their wages in order to maximize the discounted sum of their current and future utility, given the probability that their wages remain effective in the subsequent periods. This optimization problem leads, after some mathematical manipulation, to the derivation of wage Phillips curve.

A modification of Calvo price (wage) setting mechanism, proposed by Galí and Gertler (1999), is often employed in literature. According to this modification, from $\theta$ portion of agents which cannot optimizes a $\omega$ portion of agents uses a simple rule-of-thumb and adjusts their prices (wages) according to the past inflation, and a 1- $\omega$ portion of agents leaves their price (wage) unchanged. ${ }^{1}$

\footnotetext{
${ }^{11}$ An identical equation can be derived using a different assumption that all non-optimizing agents partially adjust their prices according to past inflation.
} 
As mentioned earlier, New Keynesian Phillips curve can be also derived using the assumption of quadratic costs of price adjustment, see Rotemberg (1982). Under such assumption, firms can reoptimize their prices whenever they want. However, every price adjustment is costly and these adjustment costs depend quadratically on the magnitude of the price adjustment.

DSGE models with sticky prices were subjected to much criticism, most of which was related to gaps between model implications and empirical facts. Ball (1994) pointed on the fact that models with staggered price adjustment imply surprising result that announced, credible disinflations cause booms rather than recessions. Fuhrer and Moore (1995) argue that sticky price models cannot explain observed persistence of inflation. Mankiw (2001) notes that sticky price models imply instant response of inflation to shocks in monetary policy, followed by a relatively quick convergence of inflation to the steady state. He argued that these models have trouble explaining why shocks to monetary policy have a delayed and gradual effect on inflation.

The criticism of sticky price models mentioned in the previous paragraph inspired some economists to consider another type of nominal rigidities - sticky information. These models are often labeled as SIGE models (Sticky Information General Equilibrium models). The fundamental assumption of these models is that information about macroeconomic conditions disseminate slowly through the economy. The reason may be either costs of acquiring information or costs of reoptimization. The advantage of these models is that they employ only one type of rigidities - sticky information.

Mankiw and Reis $(2001,2002)$ introduce the concept of sticky information and apply it on decision making process of households/firms and the resulting behavior of prices/wages. Reis (2006a, 2006b) discusses these issues in more detail. He examines conditions under which firms prefer setting a plan for prices they charge instead of setting a plan for quantity they sell. He also offers an explanation for why agents rationally choose to be inattentive to news, thus only sporadically updating their information. Mankiw and Reis (2007) and Reis (2009a) present the concept of sticky information in a fully articulated DSGE model, in the former case estimated on the data of the U.S. economy, in the latter case on the data of the U.S. and Euro Area economy. Ball, Mankiw and Reis (2005) and Reis (2009b) examine the issue of optimal monetary policy in SIGE model, from the theoretical point of view in the former case, in an empirical application on the U.S. economy in the latter case. Mankiw and Reis (2006) summarize the main features and implications of sticky information models and discuss how they correspond with empirical facts. Mankiw and Reis (2010) offers a survey of the research on imperfect information models of aggregate supply and the Phillips curve.

The proponents of sticky information models argue that these models are more consistent in several aspects with the commonly held view on the effects of monetary policy than sticky price models. Unlike sticky price models, sticky information models imply that disinflations are always contractionary (although announced disinflations are less contractionary than surprising ones), while sticky price models allow for a boom after an announced, credible disinflation. As regards the effects of monetary policy 
shocks, according to sticky price models, the maximum impact of a monetary shock on inflation occurs immediately, while in sticky information models the maximum impact on inflation occurs with a substantial delay - after 7 quarters. This result is more in line with the results of empirical studies on the lags of monetary policy, for example see seminal paper by Friedman (1972) or a more recent study by Batini and Nelson (2001). Sticky information models are also more consistent with the acceleration phenomenon, i.e. inflation tends to rise when economy is booming and falls when economic activity is depressed, thus implying that the change in inflation is positively correlated with the level of economic activity. Sticky price models, on the contrary, usually imply a rather small correlation with a negative sign.

On the other hand, Pytlarczyk (2007) demonstrates, using Bayes factor, that models with Calvo price setting mechanism fit the macroeconomic data of the Euro Area better than models with sticky information. It should be also noted that although sticky information models were published in highly-appreciated journals, sticky price models are still considered to be the benchmark in macro-modeling practice.

\section{Theoretical Background of Rigidities}

The assumptions of price and wage rigidities are based on extensive literature of New Keynesian economics. New Keynesian economics focuses mainly on providing microeconomic foundations for such assumptions, and tries to show how these patterns of an economy produce Keynesian macroeconomic effects known from basic textbooks. ${ }^{12}$

\section{Explicit Contracts}

At first, attention of New Keynesian economists focused on nominal rigidities implied by long-term contracts. Fischer (1977) and Taylor (1980) examined consequences of long-term wage contracts on effects of monetary policy. Similarly, Phelps and Taylor (1977) examined consequences of long-term agreements about prices and wages on the potential of monetary policy, concluding that existence of long-term wage (price) contracts can generate sufficient nominal wage (price) rigidity for monetary policy to be potentially welfare enhancing.

In the papers mentioned in the previous paragraph, authors do not examine reasons for formation of long-term contracts, and they take it for granted that there is a "revealed preference" for this type of contracts. Phelps $(1985,1990)$ provides a rationale for longterm wage contracts: (i) wage negotiations are costly in time for both workers and firms; the longer the period of the contract, the less frequently are these transaction costs incurred; (ii) negotiations may fail and workers may resort to strike action in order to improve their bargaining position; and (iii) if the firm lowers wage paid to its employees following a negative demand shock and other firms do not, it reduces its relative wage, thus possibly increasing labor turnover, which is costly to the firm.

\footnotetext{
${ }^{12}$ A representative collection of the most influential papers can be found in Mankiw and Romer (1991a) and Mankiw and Romer (1991b). A nice non-technical overview of the most important New Keynesian theories and their implications is presented in Snowdon and Vane (2005) or Sojka (2010).
} 
As regards rationale for the long-term price contracts, similar argument can be made about costly negotiations of prices between producers and retailers. If these negotiations are costly, it can be optimal for both sides to enter into a long-term contract. Gordon (1981) also argues that heterogeneity in types and quality of products in a market economy is so huge that determining each price in an auction would create overwhelming transaction costs. Use of pre-set price tags, which can be viewed as a form of long-term price contracts, is a rational response to the problem of heterogeneity.

The impact of long-term contracts also depends on whether the contract renegotiations are synchronized (like the shunto system for negotiating wages in Japan), or whether the economy has the non-synchronized system of overlapping (staggered) contracts. In the latter case, nominal prices (wages) exhibit more inertia in the face of shocks than in the former case. Taylor (1980) shows that if wage contracts are staggered and workers are concerned with their wage relative to others, then the impact of monetary policy on real variables persists well beyond the length of the contracting period. Ball and Cecchetti (1988) show how staggered price setting can arise as a rational response of firms to an imperfect information environment. ${ }^{13}$

\section{Implicit Contracts}

Theory of "implicit price contracts" is related to efforts of firms to maintain its regular customers. Okun $(1975,1981)$ coined the term "customer market" for markets where there is a relatively low frequency of searches in comparison to frequency of purchase due to substantial costs of searching the market for customers. In such circumstances, sellers have certain monopoly power even though there may be many firms in the market that sell a similar product. Because many customers make repetitive purchases, it is of an interest of a firm to discourage customers from searching the market for a better price. Frequent price changes will provide incentives for customers to look elsewhere. While customers notice a price increase immediately, a price decrease produces smaller response among customers because it takes time for such information to be noticed by customers of other firms. Together with efforts of a firm to maintain its regular customers, this asymmetry in responses of customers results in relative price stickiness.

Theory of "implicit wage contracts", see Baily (1974), Gordon (1974), and Azariadis (1975), provides an explanation for real wage rigidity. This theory tries to explain why labor markets experience a turnover that is relatively lower than what the competitive wage theory implies. It also helps to explain why the real wage frequently diverges from the marginal productivity of labor. According to the competitive wage theory, firms react to a contraction in product demand by lowering both employment and the real wage rate. On the contrary, a usual industrial practice is that firms lay off redundant workers, and pay unchanged wages to the rest of the workforce. According to the "implicit wage contracts" theory, some firms and some workers enter the unwritten (implic-

\footnotetext{
${ }^{13}$ In their model, firms have imperfect knowledge of the current state of the economy and gain information by observing the prices set by others. This gives each firm an incentive to set its price shortly after other firms set theirs. Staggering can be the equilibrium outcome. In addition, the information gains can make staggering socially optimal even though it increases aggregate fluctuations. Ball and Cecchetti (1988, p. 999)
} 
it) agreements about the terms of their working contracts. This "invisible handshake" provides employees with an assurance about the terms of their working contract under variety of external circumstances. From the firm's perspective, it improves loyalty of the key workers and hence reduces their turnover. In the models of Baily (1974), Gordon (1974) and Azariadis (1975), firms have better access to the capital market than workers. In such circumstances, smooth real wage serves also as an insurance provided by the risk-neutral firms to the risk-averse workers. Because firms provide stable wages to workers, they are, on the other hand, willing to accept a real wage which is on the average lower than the highly volatile real wage which would otherwise prevail on the labor market.

\section{Efficiency Wages}

Theory of "efficiency wages" provides a rationale for the real wage rigidity. ${ }^{14}$ Solow (1979) provides the basic idea of the "efficiency wages" theory. Using a simple model, he shows that if working efforts of workers are positively related to the real wage rate, employers may be motivated to set wages above the equilibrium wage in order to increase productivity of their employees. The idea of a positive correlation between efforts of the workers and the real wage rate seems to be very old, some notes on this topic can be find in as early works as that by Marshall (1920). The theory of "efficiency wages" gained popularity in the area of development economics, see Leibenstein (1957) or Bardhan (1993), where the explanation of the relationship between the real wage rate and the efforts of workers is based on the fact that higher wages reduce malnutrition in developing countries, thus increasing labor productivity. Of course, a different explanation is needed for modern developed economies. Basically, economic literature distinguishes four main categories of "efficiency wages" theory: (i) the adverse selection models, where higher wages attract better workers, (ii) the labor turnover models, where higher wages reduce worker turnover, (iii) the shirking models, where it is inadequate or too costly for employers to monitor worker's efforts, and "efficiency wages" provide workers with the incentive to work rather than shirk, and (iv) sociological models which accent the role of sociological factors, such as equity or fairness, and their perception by workers, and their impact on the working effort of workers.

\section{Menu Costs}

Many theories accent costs implied by flexible price (wage) setting. Mankiw (1985) coins the term "menu costs" for costs associated with frequent price changes. He shows that these "menu costs" can prevent firms from setting their prices optimally, thus causing private profit losses which are, however, lower than these "menu costs". Nevertheless, as pointed by Mankiw (1985) and elaborated further by Blanchard and Kiyotaki (1987), such nominal price rigidity generates negative aggregate demand externality, causing significant losses of the aggregate output and employment, and thus generating large business cycle fluctuations. Similarly, Akerlof and Yellen (1985a, 1985b) coin the term "near-rational behavior" for the behavior of firms which use simple rules of price

\footnotetext{
${ }^{14}$ For detailed discussion and extensive survey of the literature see Yellen (1984), Katz (1986), Haley (1990) or Weiss (1991). The collection of the most influential papers focusing on "efficiency wages" can be found in Akerlof and Yellen (1986).
} 
(wage) formations. These firms deviate from the optimal price (wage) setting, however, they reduce their transaction costs associated with searching information about demand (labor supply) changes. In such case, profit losses caused by deviations of prices (wages) from their optimal value can be, more than one by one, offset by reductions of their transaction costs. However, such behavior (which is optimal from the firm's perspective) causes significant losses of aggregate output and employment.

The "menu costs" literature, such as the works of Mankiw (1985), Blanchard and Kiyotaki (1987) and Akerlof and Yellen (1985a, 1985b), was subjected to some criticism. Ball and Romer (1989) show that small frictions in nominal adjustment, such as costs of changing prices, generate negative demand externalities and cause losses of the aggregate output and employment. However, they also show that the effect is quantitatively small for plausible parameter values. Nevertheless, in the subsequent paper Ball and Romer (1990) demonstrate that real rigidities amplify non-neutralities resulting from small nominal frictions, implying that substantial nominal rigidities can arise from combination of small nominal frictions and real rigidities.

Other Sources of Rigidity

Adjusting other elements of products: Carlton $(1986,1987)$ suggests that price rigidity may be a result of the fact that in response to the cost or demand shock, firms may find it optimal to vary other elements of the product, such as delivery lags, service, product quality, and so forth, instead of adjusting prices.

Input-output tables: Gordon (1981) argues that modern firms are connected with each other via complex input-output tables. In such circumstances, firms buy many ingredients from other firms, many of which are from foreign countries. Therefore, for a given firm there is no certainty that their marginal revenue and marginal costs will move in the same direction and proportion following an aggregate demand shock. Besides providing explanation for the real price rigidity, this theory also provides explanation for the nominal price rigidity. In the real uncertain world where information is inevitably imperfect, gradual adjustment of prices can be the optimal response of the firms to the aggregate demand shock, see Ball and Cecchetti (1988).

Coordination failure: Ball and Romer (1991) argue that substantial price rigidity may arise as a result of coordination failure on the supply side. If a firm's desired price is increasing in others' prices, then the gain from price adjustment after a nominal shock is greater if others adjust. ${ }^{15}$ For example, firms may hesitate to increase their prices after a negative cost shock until their competitors do so because they are afraid of losing customers.

Judging quality by price: Stiglitz (1987) examines another source of real price rigidity. This source is based on imperfect information of customers. He offers another explanation why firms may be reluctant to reduce prices while facing a negative aggregate demand shock. In markets where customers have imperfect information about quality of products, they may judge it according to their prices. In such circumstances, firms may

${ }^{15}$ Ball and Romer (1991, p. 539) 
be reluctant to lower their prices because they do not want to risk that customers will interpret this action as a signal indicating a deterioration of quality.

\section{Empirical Evidence of Rigidities}

As there are many microeconometric studies and surveys which deal with empirical evaluation of price and wage stickiness, I decided to focus only on the most comprehensive, the most recent, and the most cited ones.

Taylor (1998) summarizes previous evidence from empirical studies focusing on evaluation of price and wage stickiness, most of which deal with the U.S. economy. He concludes that: (i) the average frequency of price adjustment, as well as wage adjustment, is about one year; (ii) there is a great deal of heterogeneity in price and wage setting schemes among product categories and labor types; (iii) neither price setting nor wage setting is synchronized; and (iv) frequency of price and wage changes depends on the average rate of inflation. The fact that neither price setting nor wage setting is synchronized suggests that the main assumption about price (wage) stickiness used in New Keynesian models, i.e. staggering price (wage) setting, provides a good approximation of a firm's price (household's wage) setting behavior. However, the fact that the frequency of price and wage changes depends on the average rate of inflation seems to slightly challenge the Calvo price (wage) setting mechanism used in New Keynesian models, which assumes that the frequency of price and wage adjustments is constant.

Bils and Klenow (2004) provide very different results about the average frequency of price adjustment. They examine data underlying CPI in USA and estimate the median duration of prices between 4 and 6 months, which implies a much more frequent price adjustment than in most previous empirical studies. They also find out that the frequency of price changes differs dramatically across goods. However, Nakamura and Steinson (2008) call into question their results about average frequency of price adjustment, showing that using a more detailed data set and excluding price changes associated with sales, the estimated median duration of prices is in the range between 8 and 11 months. They also find out that the frequency of price change is highly seasonal, being highest in the first quarter and declining subsequently.

Blinder (1991, 1994) comes up with a new methodology for evaluating price stickiness and its sources based on interviews with managers of companies from the North East of the USA. He finds out that (i) a median firm adjusts its prices once a year; (ii) lags in price adjustment after a shock last typically for about three months; (iii) there is almost no evidence that price adjustment occurs more rapidly upward than downward; and (iv) there is no evidence that firms respond to cost shocks more rapidly than to demand shocks. As regards the sources of price stickiness, the most important theories appear to be (i) coordination failure, see Ball and Romer (1991); (ii) lagged cost-based pricing, see Gordon (1981); (iii) adjusting other elements of the product, such as delivery lags, service, etc., see Carlton (1986, 1987); and (iv) implicit contracts with customers, see Okun $(1975,1981)$, while "judging by price" theory, see Stiglitz (1987), appeared to be totally unimportant.

Bhaskar et al. (1993) also use methodology based on interviews with managers of a sample of small firms in the UK in the mid-1980s. They find that firms use quantity 
adjustments rather than price adjustments in response to demand shocks. Most firms do not raise prices in booms and lower them in recessions while quantity adjustments, e. $\mathrm{g}$. variations in hours, shift work, inventories or customer rationing, are much more important.

A unique project of researchers from the European Central Bank and the national central banks of the Eurosystem called Inflation Persistence Network (henceforth IPN) was being carried out from 2003 to 2005. It was a coordinated research project on the patterns, determinants and implications of inflation persistence in the euro area and in its member countries. ${ }^{16}$ Researchers examined (i) data underlying CPI, HICP, and PPI; (ii) data from the survey on price setting behavior of firms; and (iii) macroeconomic data. A lot of interesting papers was published as a part of this research project, nevertheless, in this review I restrict my attention to those which summarize the main findings of this giant research project related to the issue of price stickiness. ${ }^{17} \mathrm{~A}$ brief overall summary of findings can be found in Altissimo et al. (2006a). The main findings are that prices in the retail sectors remain unchanged on average for four to five quarters while price changes in the producer sectors are little bit more frequent, a median firm changes prices of its products once a year. The most important reasons of price stickiness are (i) long-term relationships with customers; (ii) explicit contracts which are costly to renegotiate; and (iii) coordination problems arising from the fact that firms prefer not to change prices unless their competitors do so. Menu costs and costs of gathering information are reported to be of lesser importance. There is also significant sectoral heterogeneity in the degree of price stickiness. Price changes are very frequent for energy and unprocessed food, but relatively infrequent for non-energy industrial goods and services. There is also no evidence of general downward price rigidity, price decreases are not uncommon, except for in services.

Angeloni et al. (2006) discusses the implications of IPN results for macro modeling and conclude that the basic Calvo price setting mechanism (possibly extended to allow for sectors with different degrees of price stickiness) may not be a bad approximation of the reality.

As regards the price setting behavior in the Czech economy, Murárik (2011) examines price changes using data from the retail stores. Basically, his results corroborate the main findings from examining HICP and CPI within IPN project which are summarized in Dhyne, et al. (2006).

\footnotetext{
${ }^{16}$ See http://www.ecb.int/home/html/researcher_ipn.en.html.

17 For the full list of papers published within this research project, see http://www.ecb.int/home/html/researcher_ipn_papers.en.html. The main findings from examining PPI are summarized in Vermeulen et. al. (2007) and the main findings from examining HICP and CPI are summarized in Dhyne, et al. (2006). The main results of the survey on price setting behavior of firms are discussed in Fabiani et al. (2005). The main findings from examining microeconomic data are briefly summarized in Álvarez et al. (2006), while the main findings from examining macroeconomic data are summarized in Altissimo et al. (2006b).
} 


\section{Conclusion}

This paper discusses the historical, theoretical, and empirical background of DSGE models. I have shown that the fundament of these models lies in optimizing agents framework. I argue which impulses fueled the development of DSGE models, and that all of them were related to the widened dissatisfaction of economists with large-scale neo-Keynesian macroeconometric models, on both theoretical and practical level. The evolution of DSGE model is demonstrated with an accent on the role and effects of the monetary policy, using distinction between RBC models and New Keynesian models. I discuss the main features of both RBC and New Keynesian models and explain the paradigm shift from the RBC models to the New Keynesian models by pointing out the main pitfalls of the RBC models and showing how adding some "Keynesian" assumptions, namely nominal rigidities, to the otherwise standard RBC models enhances empirical properties of these models. I also discuss how these assumptions are modeled in New Keynesian DSGE models and what the pros and cons of different approaches are. Finally, I review the most important New Keynesian theories of nominal rigidities and some of the empirical evidence on price and wage rigidities.

\section{References}

AKERLOF, G. A., YELLEN, J. L. (1985a). A Near-Rational Model of Business Cycle with Wage and Price Inertia. Quarterly Journal of Economics, 100(Supplement), pp. 823-838.

AKERLOF, G. A., YELLEN, J. L. (1985b). Can Small Deviations from Rationality Make Significant Differences to Economic Equilibria? American Economic Review, 75(4), pp. 708-720.

AKERLOF, G. A., YELLEN, J. L., (eds.), (1986). Efficiency Wage Models of the Labor Market. Cambridge: Cambridge University Press.

ALTISSIMO, F., EHRMANN, M., SMETS, F. (2006a). Inflation Persistence and PriceSetting Behaviour in the Euro Area: A Summary of the IPN Evidence. European Central Bank, Occasional Paper Series 46.

ALTISSIMO, F., BILKE, L., LEVIN, A., MATHÄ, T., MOJON, B. (2006b). Sectoral and Aggregate Inflation Dynamics in the Euro Area. Journal of the European Economic Association, 4(2-3), pp. 585-593.

ÁLVAREZ, L. J., et al. (2006). Sticky Prices in the Euro Area: A Summary of New Micro-Evidence. Journal of the European Economic Association, 4(2-3), pp. 575-584.

ANGELONI, I., et al. (2006). New Evidence on Inflation Persistence and Price Stickiness in the Euro Area: Implications for Macro Modeling. Journal of the European Economic Association, 4(2-3), pp. 562-574.

AZARIADIS, C. (1975). Implicit Contracts and Underemployment Equilibria. Journal of Political Economy, 83(6), pp. 1183-1202.

BAILY, M. N. (1974). Wages and Employment under Uncertain Demand. Review of Economic Studies, 41(1), pp. 37-50. 
BALL, L. (1994). Credible Disinflation with Staggered Price Setting. American Economic Review, 84(1), pp. 282-289.

BALL, L., CECCHETTI, S. G. (1988). Imperfect Information and Staggered Price Setting. American Economic Review, 78(5), pp. 999-1018.

BALL, L., MANKIW, N. G., REIS, R. (2005). Monetary Policy for Inattentive Economies. Journal of Monetary Economics, 52(4), pp. 703-725.

BALL, L., ROMER, D. (1989). Are Prices too Sticky? Quarterly Journal of Economics, 104(3), pp. 507-524.

BALL, L., ROMER, D. (1990). Real Rigidities and the Non-Neutrality of Money. Review of Economic Studies, 57(2), pp. 183-203.

BALL, L., ROMER, D. (1991). Sticky Prices as Coordination Failure. American Economic Review, 81(3), pp. 539-552.

BARDHAN, P. (1993). Economics of Development and the Development of Economics. Journal of Economic Perspectives, 7(2), pp. 129-142.

BATINI, N., NELSON, E. (2001). The Lag from Monetary Policy Actions to Inflation: Friedman Revisited. International Finance, 4(3), pp. 381-400.

BHASKAR, V., MACHIN, S., REID, G. C. (1993). Price and Quantity Adjustment over the Business Cycle: Evidence from Survey Data. Oxford Economic Papers, 45(2), pp. 257-268.

BILS, M., KLENOW, P. J. (2004). Some Evidence on the Importance of Sticky Prices. Journal of Political Economy, 112(5), pp. 947-985.

BLANCHARD, O., KIYOTAKI, N. (1987). Monopolistic Competition and the Effects of Aggregate Demand. American Economic Review, 77(4), pp. 647-666.

BLINDER, A. S. (1991). Why are Prices Sticky? Preliminary Results from an Interview Study. American Economic Review, 81(2), pp. 89-96.

BLINDER, A. S. (1994). On Sticky Prices: Academic Theories Meet the Real World. In Mankiw (ed.), Monetary Policy. Chicago: University of Chicago Press.

CALVO, G. (1983). Staggered Prices in a Utility-maximizing Framework. Journal of Monetary Economics, 12(3), pp. 383-398.

CARLTON, D. W. (1986). The Rigidity of Prices. American Economic Review, 76(4), pp. 637-658.

CARLTON, D. W. (1987). The Theory and the Facts of How Markets Clear: Is Industrial Organization Valuable for Understanding Macroeconomics? NBER Working Paper No. 2178.

CHRISTIANO, L. J., EICHENBAUM, M., EVANS, C. L. (1998). Monetary Policy Shocks: What Have We Learned and to What End? NBER Working Paper No. 6400.

COENEN, G., STRAUB, R. (2005). Does Government Spending Crowd in Private Consumption? Theory and Empirical Evidence for the Euro Area. International Finance, 8(3), pp. 435-470. 
DIEBOLD, F. X. (1998). The Past, Present, and Future of Macroeconomic Forecasting. Journal of Economic Perspectives, 12(2), pp. 175-192.

DHYNE, E., et al. (2006). Price Changes in the Euro Area and the United States: Some Facts from Individual Consumer Price Data. Journal of Economic Perspectives, 20(2), pp. 171-192.

ERCEG, C. J., HENDERSON, D. W., LEVIN, A. T. (2000). Optimal Monetary Policy with Staggered Wage and Price Contracts. Journal of Monetary Economics, 46(2), pp. 281-313.

FABIANI, S., et al. (2005). The Pricing Behaviour of Firms in the Euro Area: New Survey Evidence. ECB Working Paper No. 535.

FISHER, S. (1977). Long-term Contracts, Rational Expectations, and the Optimal Money Supply Rule. Journal of Political Economy, 85(1), pp. 191-205.

FRIEDMAN, M. (1972). Have Monetary Policies Failed? American Economic Review, 62(1/2), pp. 11-18.

FRIEDMAN, M., SCHWARTZ, A. J. (1963). A Monetary History of the United States, 1867-1960. Princeton: Princeton University Press.

GALÍ, J. (2008). Monetary Policy, Inflation, and the Business Cycle: An Introduction to the New Keynesian Framework. Princeton: Princeton University Press.

GALÍ, J., GERTLER, M. (1999). Inflation Dynamics: A Structural Econometric Analysis. Journal of Monetary Economics, 44(2), pp. 195-222.

GALÍ, J., RABANAL, P. (2005). Technology Shocks and Aggregate Fluctuations: How Well Does the RBC Model Fit Postwar U.S. Data? IMF Working Paper 04/234.

GOODFRIEND, M., KING, R. G. (1997). The New Neoclassical Synthesis and the Role of Monetary Policy. NBER Macroeconomics Annual, 12, pp. 231-296.

GORDON, D. F. (1974). A Neo-Classical Theory of Keynesian Unemployment. Economic Inquiry, 12(4), pp. 431-459.

GORDON, R. J. (1981). Output Fluctuations and Gradual Price Adjustment. Journal of Economic Literature, 19(2), pp. 493-530.

HALEY, J. (1990). Theoretical Foundations of Sticky Wages. Journal of Economic Surveys, 4(2), pp. 115-155.

KATZ, L. F. (1986). Efficiency Wage Theories: A Partial Evaluation. NBER Macroeconomics Annual, 1, pp. 235-290.

KEYNES, J. M. (1936). The General Theory of Employment, Interest and Money. London: Macmillan (reprinted 2007).

KING, R. G., REBELO, S. T. (1999). Resuscitating Real Business Cycles. NBER Working Paper No. 7534.

KLEIN, L. R., GOLDBERGER, A. S. (1955). An Econometric Model of the United States: 1929-1952. Amsterdam: North-Holland. 
KYDLAND, F. E., PRESCOTT, E. C. (1982). Time to Build and Aggregate Fluctuations. Econometrica, 50(6), pp. 1345-1370.

LEIBENSTEIN, H. (1957). Economic Backwardness and Economic Growth. New York: Wiley.

LONG, J. B., PLOSSER, C. I. (1983). Real Business Cycles. Journal of Political Economy, 91(1), pp. 39-69.

LUCAS, R. E. (1972). Expectations and the Neutrality of Money. Journal of Economic Theory, 4, pp. 103-124.

LUCAS, R. E. (1976). Econometric Policy Evaluation: A Critique. Carnegie Orchester Conference Series on Public Policy, 1(1), pp. 19-46.

LUCAS, R. E., PRESCOTT, E. C. (1971). Investment Under Uncertainty. Econometrica, 39(5), pp. 659-681.

MANKIW, N. G. (1985). Small Menu Costs and Large Business Cycles: A Macroeconomic Model of Monopoly. Quarterly Journal of Economics, 100(2), pp. 529-537.

MANKIW, N. G. (2000). The Savers-Spenders Theory of Fiscal Policy. American Economic Review, 90(2), pp. 120-125.

MANKIW, N. G., REIS, R. (2001). Sticky Information: A Model of Monetary Nonneutrality and Structural Slumps. NBER Working Paper No. 8614.

MANKIW, N. G., REIS, R. (2002). Sticky Information Versus Sticky Prices: A Proposal To Replace The New Keynesian Phillips Curve. Quarterly Journal of Economics, 117(4), pp. 1295-1328.

MANKIW, N. G., REIS, R. (2006). Pervasive Stickiness. American Economic Review, 96(2), pp. 164-169.

MANKIW, N. G., REIS, R. (2007). Sticky Information in General Equilibrium. Journal of the European Economic Association, 5(2-3), pp. 603-613.

MANKIW, N. G., REIS, R. (2010). Imperfect Information and Aggregate Supply. NBER Working Paper No. 15773.

MANKIW, N. G., ROMER, D., (eds.), (1991a). New Keynesian Economics, vol.1, Imperfect Competition and Sticky Prices. Cambridge: MIT Press.

MANKIW, N. G., ROMER, D., (eds.), (1991b). New Keynesian Economics, vol.2, Coordination Failures and Real Rigidities. Cambridge: MIT Press.

MARSHALL, A. (1920). Principles of Economics. (Revised Edition ed.). London: Macmillan; reprinted by Prometheus Books.

MURÁRIK, R. (2011). Price Setting Behaviour in the Czech Republic, Micro Data Evidence. Statistika: Statistics and Economy Journal, 2011, pp. 24-41.

MUTH, J. F. (1961). Rational Expectations and the Theory of Price Movements. Econometrica, 29(3), pp. 315-335. 
NAKAMURA, E., STEINSSON, J. (2008). Five Facts about Prices: A Reevaluation of Menu Costs Models. Quarterly Journal of Economics, 123(4), pp. 1415-1464.

NELSON, C. R. (1972). The Prediction Performance of the F.R.B.-M.I.T.-Penn Model of the U.S. Economy. American Economic Review, 62(5), pp. 902-917.

OKUN, A. (1975). Inflation: Its Mechanics and Welfare Cost. Brookings Papers on Economic Activity, 2, pp. 351-401.

OKUN, A. (1981). Prices and Quantities: A Macroeconomic Analysis. Washington: Brookings Institution.

PHELPS, E. S. (1985). Political Economy: An Introductory Text. New York: W. W. Norton.

PHELPS, E. S. (1990). Seven Schools of Macroeconomic Thought. Oxford: Oxford University Press.

PHELPS, E. S., TAYLOR, J. B. (1977). Stabilizing Powers of Monetary Policy under Rational Expectations. Journal of Political Economy, 85(1), pp. 163-190.

PRESCOTT, E. C. (1986). Theory Ahead of Business Cycle Measurement. Quarterly Review, 10, pp. 9-22.

PYTLARCZYK, E. (2007). Construction and Bayesian Estimation of DSGE Models for the EURO Area - A Statistical Framework. Saarbrücken: VDM Verlag Dr. Müller.

REBELO, S. (2005). Real Business Cycle Models: Past, Present, and Future. Scandinavian Journal of Economics, 107(2), pp. 217-238.

REIS, R. (2006a). Inattentive Producers. Review of Economic Studies, 73(3), pp. 793 821.

REIS, R. (2006b). Inattentive Consumers. Journal of Monetary Economics, 53(8), pp. $1761-1800$

REIS, R. (2009a). Optimal Monetary Policy Rules in an Estimated Sticky-Information Model. American Economic Journal: Macroeconomics, 1(2), pp. 1-28.

REIS, R. (2009b). A Sticky-Information General-Equilibrium Model for Policy Analysis. NBER Working Paper No. 14732.

ROTEMBERG, J. (1982). Monopolistic Price Adjustment and Aggregate Output. Review of Economic Studies, 49(4), pp. 517-531.

SLOBODYAN, S., WOUTERS, R. (2012). Learning in an estimated medium-scale DSGE model. Journal of Economic Dynamics and Control, 36(1), pp. 26-46.

SNOWDON, B., VANE, H. R. (2005). Modern Macroeconomics: Its Origins, Development and Current State. Cheltenham: Edward Elgar Publishing.

SOJKA, M. (2010). Dějiny ekonomických teorií. Praha: Havlíček Brain Team.

SOLOW, R. (1979). Another Possible Source of Wage Stickiness. Journal of Macroeconomics, 1(1), pp. 79-82. 
STIGLITZ, J. (1987). The Causes and Consequences of the Dependency of Quality on Prices. Journal of Economic Literature, 25(1), pp. 1-48.

SUMMERS, L. H. (1986). Some Skeptical Observations on Real Business Cycle Theory. Quarterly Review, issue Fall, pp. 23-27.

TAYLOR, J. B. (1980). Aggregate Dynamics and Staggered Contracts. Journal of Political Economy, 88(1), pp. 1-23.

TAYLOR, J. B. (1998). Staggered Price and Wage Setting in Macroeconomics. NBER Working Paper No. 6754.

VERMEULEN, P., et al. (2007). Price Setting in the Euro Area: Some Stylised Facts from Individual Producer Price Data. ECB Working Paper No. 727.

WEISS, A. (1991). Efficiency Wages: Models of Unemployment, Layoffs and Wage Dispersion, Princeton: Princeton University Press.

WOODFORD, M. (2003). Interest and Prices: Foundations of a Theory of Monetary Policy.Princeton: Princeton University Press.

YELLEN, J. L. (1984). Efficiency Wage Models of Unemployment. American Economic Review, 74(2), pp. 200-205.

YUN, T. (1996). Nominal Price Rigidity, Money Supply Endogeneity, and Business Cycles. Journal of Monetary Economics, 37(2-3), pp. 345-370. 